\title{
15. BASE OF LARGE GEPHYROCAPSA AND ASTRONOMICAL CALIBRATION OF EARLY PLEISTOCENE SAPROPELS IN SITE 967 AND HOLE 969D: SOLVING THE CHRONOLOGY OF THE VRICA SECTION (CALABRIA, ITALY) ${ }^{1}$
}

\author{
L.J. Lourens, ${ }^{2}$ F.J. Hilgen, ${ }^{3}$ and I. Raffi ${ }^{4}$
}

\begin{abstract}
Calcareous plankton biochronology and the astronomical calibration of sapropels are presented for the early Pleistocene in Ocean Drilling Program (ODP) Site 967 and Hole 969D with the aim to solve the existing chronology problem in the Pliocene/ Pleistocene boundary stratotype section of Vrica, Italy. Detailed sapropel correlations between these ODP sites and the Vrica and Singa sections, corroborated by calcareous plankton biostratigraphy, indicate that the Vrica section is continuous and that the base of the large Gephyrocapsa is diachronous on a global scale.
\end{abstract}

\section{INTRODUCTION}

Recently, two alternative age models were presented for the Pleistocene part of the Pliocene/Pleistocene boundary stratotype section at Vrica (Calabria, southern Italy; Lourens et al., 1996a). The chronology of both models is based on the correlation of characteristic sapropel patterns to the average of the June and July (summer) insolation time series at $65^{\circ} \mathrm{N}$ of the $\mathrm{La} 90_{(1,1)}$ (Laskar et al., 1993) astronomical solution (Lourens et al., 1996a, 1996b). The first age model is based on the assumption that the succession at Vrica is continuous. According to this model, the position of almost all calcareous plankton datum planes relative to the oxygen isotope stages is in good agreement with that found in the adjacent northern Atlantic. The only exception is the base of large Gephyrocapsa (blG), which is found in Stage 55 in the Vrica and Singa sections (Calabria, southern Italy), whereas it occurs in Stage 48 (or the top of 49) in the open ocean (Raffi et al., 1993). This unexpectedly large discrepancy in age of the blG in the eastern Mediterranean and the open ocean cast serious doubt on the validity of this age model. As a consequence, we developed an alternative age model based on the assumption that the blG is globally (near-)synchronous. This model implies a major hiatus between the top of Calcidiscus macintyrei (tCm) and the blG in the Vrica and Singa sections. Application of this alternative model, however, leads to significant discrepancies in the position of the other calcareous plankton events.

In this paper, we aim to solve the astronomical calibration of the sapropels and thereby the existing problem of the two conflicting age models for the Pleistocene part of the Vrica section. For this purpose, we established a high-resolution biochronology for Ocean Drilling Program (ODP) Site 967 and Hole 969D for the same time interval based on an unambiguous correlation of sapropel patterns to the La90 $(1,1)$ summer insolation curve at $65^{\circ} \mathrm{N}$. To explore the possibility of a blG diachroneity, we also checked the position of this event in a high-resolution sample set of ODP Site 926 from the equatorial Atlantic.

${ }^{1}$ Robertson, A.H.F., Emeis, K.-C., Richter, C., and Camerlenghi, A. (Eds.), 1998. Proc. ODP, Sci. Results, 160: College Station, TX (Ocean Drilling Program).

${ }^{2}$ Faculty of Earth Sciences, Utrecht University, Budapestlaan 4, P.O. Box 80.021, Utrecht, The Netherlands. 1lourens@earth.ruu.nl

${ }^{3}$ Faculty of Earth Sciences, Utrecht University, Budapestlaan 4, P.O. Box 80.021, Utrecht, The Netherlands.

${ }^{4}$ Facoltà di Scienze Matematiche, Fisciche e Naturali, Università degli Studi G. D'Annunzio, Chieti Scalo, Italy.

\section{SITE 967 AND HOLE 969D}

Site 967 is situated south of Cyprus on the northern flank of a small ( $\sim 300 \mathrm{~m}$ high) ridge near the foot of the northern slope of the Eratosthenes Seamount $\left(34^{\circ} 04^{\prime} \mathrm{N}, 32^{\circ} 43^{\prime} \mathrm{E}\right)$ at a water depth of 2554 $\mathrm{m}$ (Fig. 1). The top $125 \mathrm{~m}$ of the section consists of early Pliocene to Holocene pelagic sediments and contains 80 sapropels and several intervals with mud turbidites. The sediments are relatively undisturbed, but show some small high-angle faulting and a slumped interval associated with an overlying debris-flow unit.

Hole 969D was drilled on the Mediterranean Ridge about $100 \mathrm{~km}$ south of the island of Crete $\left(33^{\circ} 50^{\prime} \mathrm{N}, 24^{\circ} 53^{\prime} \mathrm{E}\right)$ at a water depth of $2192 \mathrm{~m}$ (Fig. 1). The sediments of Pliocene to Holocene age consist of nannofossil oozes and nannofossil clays and contain more than 80 sapropels. The sapropels occur in five distinct groups, which are separated by intervals of yellowish brown sediment that is commonly oxidized and does not contain (preserved) sapropels. In contrast to those of Holes 969A, 969B, and 969E, the sapropels recovered from Hole 969D are intact and undeformed.

\section{BIOSTRATIGRAPHY}

We carried out our own high-resolution biostratigraphic study for the $\mathrm{tCm}, \mathrm{blG}$, and the top of large Gephyrocapsa (tlG) and top of

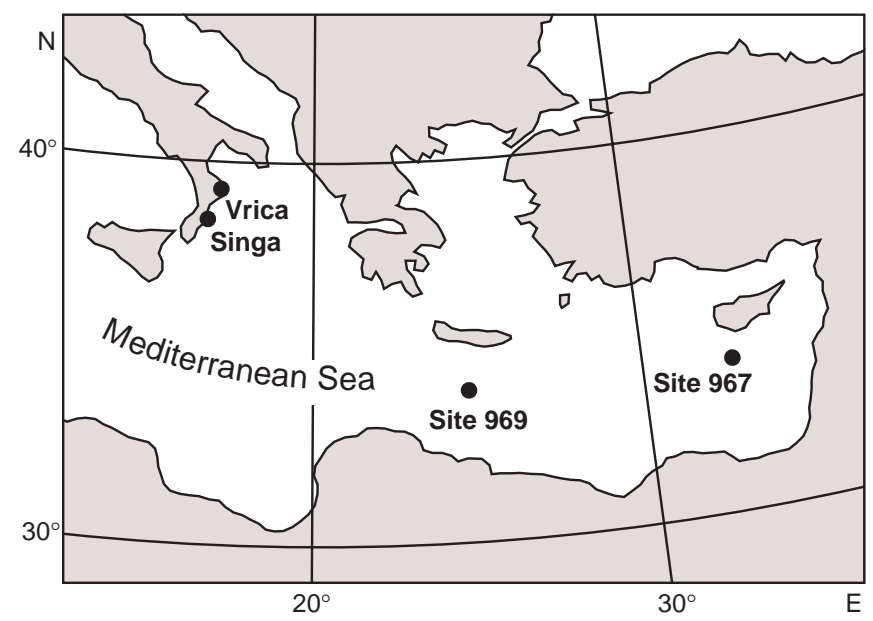

Figure 1. Location map of the studied sections and ODP sites. 
Helicosphaera sellii (tHS) in Site 967 and Hole 969D to prevent the use of different taxonomic concepts in this study and that of the Vrica section. In addition, we determined the first occurrence (FO) of the benthic foraminifer species Hyalinea balthica, checked for short influxes of the planktonic foraminifer species Globorotalia crassaformis and Globorotalia truncatulinoides, and counted the number of left-coiling neogloboquadrinids relative to their right-coiling counterpart. Finally, we determined the top of Discoaster brouweri $(\mathrm{tDb})$ in Hole 969D and adopted the position of this event in Holes 967A and $967 \mathrm{C}$ from the initial shipboard scientific results (Emeis, Robertson, Richter, et al., 1996) and from Staerker (Chap. 31, this volume), respectively. All biostratigraphic data are reported in Figure 2 and Table 1.
The $\mathrm{tCm}$ is found between Samples 160-967C-5H-7, 0-2 cm, and 10-12 cm, and Samples 160-969D-4H-6, 49-51 cm, and 58-60 cm. The blG is placed between Samples 160-967C-5H-6, 30-32 cm, and 40-42 cm, and between Samples 160-969D-4H-5, 100-102 cm, and $110-112 \mathrm{~cm}$. The percentage of large Gephyrocapsa increases gradually upwards and show a more complex extinction pattern, i.e., in agreement with the pattern found in other marine sequences of the Mediterranean and open ocean (Raffi et al., 1993; Lourens et al., 1996a). The tlG is placed between Samples 160-967A-5H-1, 95-97 $\mathrm{cm}$, and 115-117 cm, and between Samples 160-969D-3H-6, 45-47 $\mathrm{cm}$, and $75-77 \mathrm{~cm}$. The last occurrence of $H$. sellii is closely associated with the tlG and is placed between Samples 160-967A-5H-1, $105-107 \mathrm{~cm}$, and $115-117 \mathrm{~cm}$, and between Samples 160-969D-3H-

\section{Hole 969D}
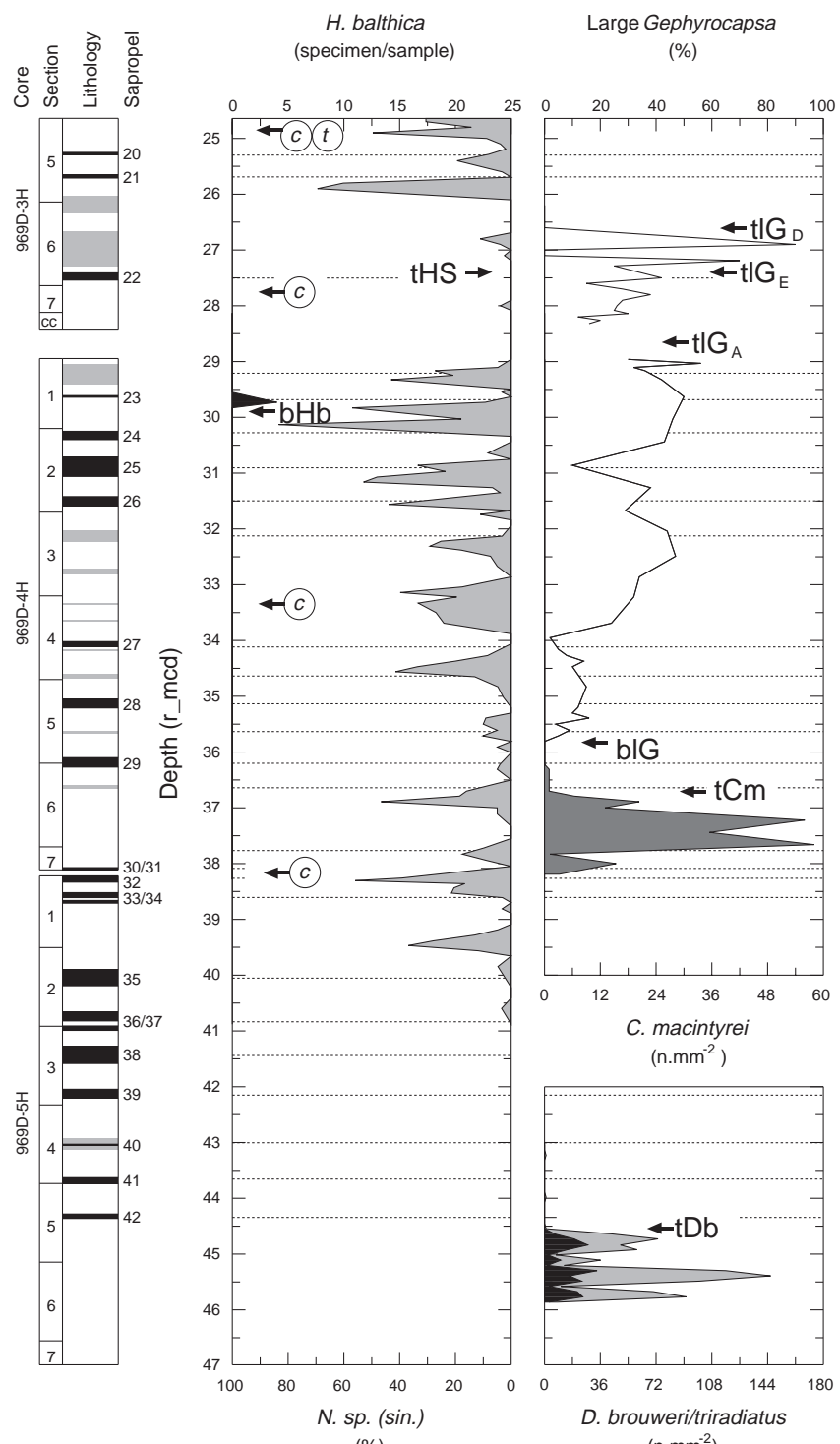

(\%)

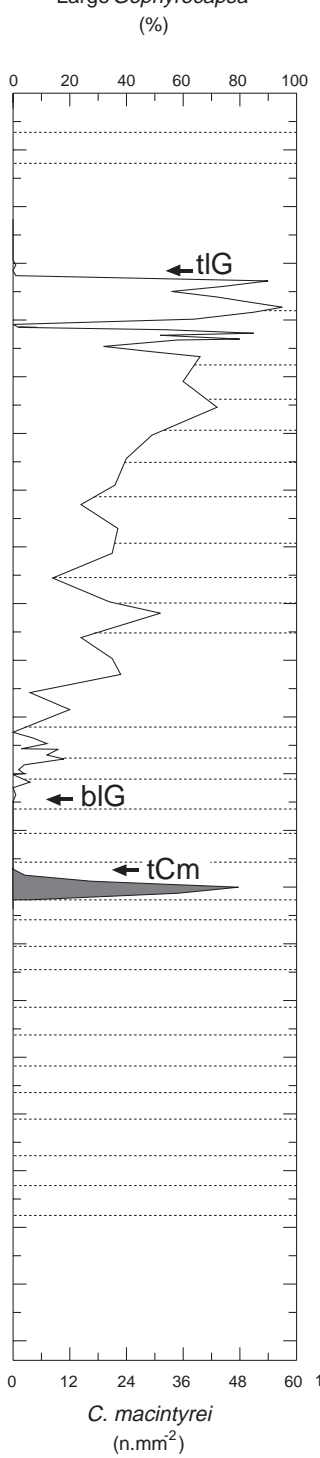

\section{Site 967}

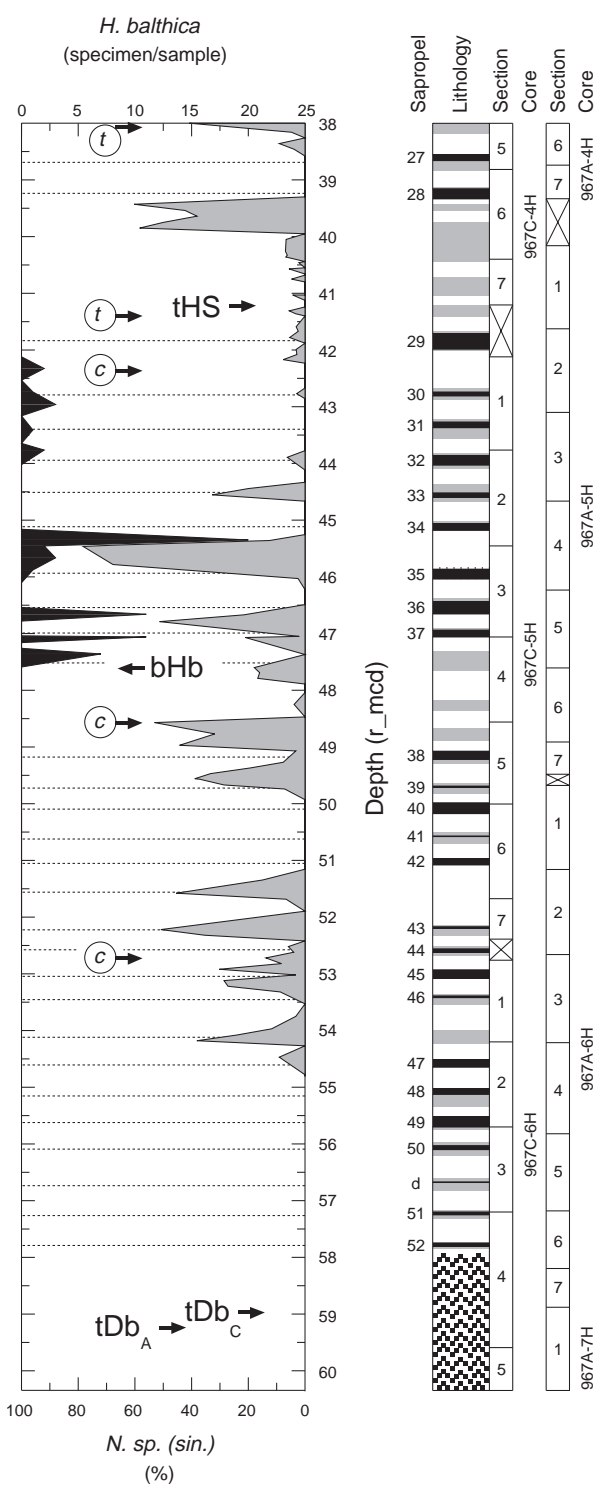

Figure 2. Biostratigraphic data of Site 967 and Hole 969D. Solid intervals in the lithology indicate sapropels, whereas the shaded areas indicate grey layers or less-distinct sapropels. The percentage of large-sized Gephyrocapsa (>5.5 $\mu \mathrm{m})$ is related to 100 Gephyrocapsa $>4 \mu \mathrm{m}$. The percentage of left-coiling neogloboquadrinids ( $N$. sp. [sin.]) is related to the total of left and right-coiling neogloboquadrinids. The percentage of Discoaster triradiatus (solid) is relative to the total of Discoaster brouweri and D. triradiatus. Influxes of Globorotalia crassaformis and Globorotalia truncatulinoides are indicated by $c$ and $t$, respectively. The jagged pattern at the bottom of the lithology column of Site 967 indicates a slumped interval. 
Table 1. Position and astronomical ages of biostratigraphic datums in Site 967, Hole 969D, and the Vrica section.

\begin{tabular}{|c|c|c|c|c|c|c|}
\hline \multirow[b]{2}{*}{ Biostratigraphic datum } & \multirow[b]{2}{*}{ Event } & \multirow{2}{*}{$\begin{array}{c}\text { Vrica } \\
\text { Age } \\
(\mathrm{Ma})\end{array}$} & \multicolumn{2}{|c|}{ Site 967} & \multicolumn{2}{|c|}{ Hole 969D } \\
\hline & & & $\begin{array}{l}\text { Depth } \\
\text { (rmcd) }\end{array}$ & $\begin{array}{l}\mathrm{Age} \\
(\mathrm{Ma})\end{array}$ & $\begin{array}{l}\text { Depth } \\
\text { (rcmd) }\end{array}$ & $\begin{array}{l}\text { Age } \\
\text { (Ma) }\end{array}$ \\
\hline \multicolumn{7}{|l|}{ Planktonic foraminifers } \\
\hline Globorotalia truncatulinoides & Influx & & 38.06 & 1.145 & 24.80 & 1.140 \\
\hline Globorotalia crassaformis & Influx & & 37.76 & 1.135 & 24.80 & 1.140 \\
\hline Neogloboquadrina sp. (sinistral) & Reappearance & 1.220 & 39.90 & 1.209 & 26.01 & 1.203 \\
\hline Globorotalia truncatulinoides & Influx & & 41.36 & 1.262 & & \\
\hline Globorotalia crassaformis & Influx & & 42.35 & 1.299 & 27.75 & 1.295 \\
\hline Neogloboquadrina sp. (sinistral) & Disappearance & 1.367 & 44.38 & 1.370 & 29.13 & 1.371 \\
\hline Globorotalia crassaformis & Influx & & 48.57 & 1.539 & 33.30 & 1.537 \\
\hline Globorotalia crassaformis & Influx & 1.723 & 52.72 & 1.722 & 38.19 & 1.727 \\
\hline Neogloboquadrina sp. (sinistral) & FCO & 1.799 & 54.23 & 1.793 & 39.51 & 1.789 \\
\hline \multicolumn{7}{|l|}{ Calcareous nannoplankton } \\
\hline Helicosphaera sellii & Top & 1.235 & 41.27 & 1.259 & 27.35 & 1.273 \\
\hline Gephyrocapsa $(>5.5 \mu \mathrm{m})$ & Top & 1.238 & 41.22 & 1.257 & 26.75 & 1.241 \\
\hline Gephyrocapsa $(>5.5 \mu \mathrm{m})$ & Base & 1.608 & 50.42 & 1.616 & 35.75 & 1.626 \\
\hline Calcidiscus macintyrei & Top & 1.671 & 51.72 & 1.673 & 36.75 & 1.663 \\
\hline Discoaster brouweri & Top & 1.947 & & & 44.60 & 1.953 \\
\hline \multicolumn{7}{|l|}{ Benthic foraminifers } \\
\hline Hyalinea balthica & FCO & 1.493 & 47.50 & 1.492 & 29.73 & 1.403 \\
\hline \multicolumn{7}{|l|}{ Polarity reversals } \\
\hline Upper Olduvai & & 1.785 & & & & \\
\hline Lower Olduvai & & 1.942 & & & & \\
\hline
\end{tabular}

Note: $\mathrm{FCO}=$ first common occurrence.

$6,114-115 \mathrm{~cm}$, and $125-127 \mathrm{~cm}$. Finally, we placed the tDb and the associated drop in Discoaster triradiatus between Samples 160969D-5H-5, 85-87 cm, and 95-97 cm.

Benthic foraminifers are scarce in Hole 969D and rare specimens of $H$. balthica are present in one sample only. H. balthica occurs more frequently in Site 967, although still in very low numbers and discontinuously. Islandiella ionica, another benthic foraminifer marker species (Verhallen, 1991), was not found. Several short peak occurrences of $G$. crassaformis and $G$. truncatulinoides were found (Table 1). The first substantial increase of left-coiling neogloboquadrinids is found between Sapropels 34 and 35 in Hole 969D and at a correlative level between Sapropels 46 and 47 in Site 967. An absence interval of this species is present between 26 and 29 revised meters composite depth (rmcd) in Hole 969D and between 40 and 44 rmcd in Site 967 (Fig. 2).

\section{SAPROPEL CHRONOLOGY}

A first-order calibration of sapropels to the astronomical record is based on the correlation of large groups or clusters of sapropels in Site 967 and Hole 969D to 400-k.y. maxima in the eccentricity of the Earth's orbit. Four distinct clusters are found between 95 and $40 \mathrm{rmcd}$ in Site 967, and between 90 and $20 \mathrm{rmcd}$ in Hole 969D. Biostratigraphic data indicate that these clusters correspond to the largescale $\mathrm{O}, \mathrm{A}, \mathrm{B}$, and $\mathrm{C}$ clusters from classical marine sections in southern Italy (e.g., Hilgen, 1991).

The oldest sapropels of the C cluster (i.e., C1-C9 in Singa and *-h in Vrica) can easily be identified in ODP Site 967 (i.e., Sapropels 4452) and Hole 969D (i.e., Sapropels 30-42; Fig. 3). The next smallscale cluster displays a cyclic alternation of distinct and less-distinct sapropels (i.e., Sapropels 38-42) in Site 967 and of sapropels and grey layers (i.e., Sapropels 27-29) in Hole 969D. These alternating distinct and less-distinct (grey) sapropel patterns can be explained by the interference between precession and obliquity, which is clearly reflected in the $\mathrm{La}_{(1,1)}$ summer insolation curve (Fig. 3): distinct sapropels are correlated to high-amplitude insolation maxima, and less-distinct (grey) sapropels are correlated to low-amplitude insolation maxima (Lourens et al., 1996b). Starting from this second-order calibration, all younger sapropels (i.e., 20-26 in Hole 969D and 27-37 in Site 967) can be correlated directly to the astronomical target curve (Fig. 3 ). The
Table 2. Position and astronomical ages of sapropels in Site 967 and Hole 969D.

\begin{tabular}{|c|c|c|c|c|c|c|}
\hline \multicolumn{4}{|c|}{ Site 967} & \multicolumn{3}{|c|}{ Hole 969D } \\
\hline i-cycle & Sapropel & $\begin{array}{l}\text { Depth } \\
\text { (rmcd) }\end{array}$ & $\begin{array}{l}\text { Age } \\
\text { (Ma) }\end{array}$ & Sapropel & $\begin{array}{l}\text { Depth } \\
\text { (rmcd) }\end{array}$ & $\begin{array}{l}\text { Age } \\
\text { (Ma) }\end{array}$ \\
\hline 110 & 27 & 38.61 & 1.164 & 20 & 25.27 & 1.164 \\
\hline 112 & 28 & 39.25 & 1.185 & 21 & 25.68 & 1.185 \\
\hline 122 & 29 & 41.85 & 1.280 & 22 & 27.48 & 1.280 \\
\hline 126 & 30 & 42.78 & 1.315 & & & 1.315 \\
\hline 128 & 31 & 43.32 & 1.335 & & & 1.335 \\
\hline 130 & 32 & 43.95 & 1.356 & & & 1.356 \\
\hline 132 & 33 & 44.56 & 1.376 & & & 1.376 \\
\hline 134 & 34 & 45.12 & 1.398 & 23 & 29.63 & 1.398 \\
\hline 138 & 35 & 45.95 & 1.429 & 24 & 30.33 & 1.429 \\
\hline 140 & 36 & 46.54 & 1.449 & 25 & 30.89 & 1.449 \\
\hline 142 & 37 & 47.00 & 1.471 & 26 & 31.51 & 1.471 \\
\hline 152 & 38 & 49.15 & 1.564 & 27 & & 1.564 \\
\hline 154 & 39 & 49.70 & 1.584 & & & 1.584 \\
\hline 156 & 40 & 50.08 & 1.603 & 28 & 34.07 & 1.603 \\
\hline 158 & 41 & 50.58 & 1.622 & & & 1.622 \\
\hline 160 & 42 & 51.03 & 1.642 & 29 & 35.13 & 1.642 \\
\hline 166 & 43 & 52.19 & 1.694 & & & 1.694 \\
\hline 168 & 44 & 52.59 & 1.715 & $30 / 31$ & 38.24 & 1.715 \\
\hline 170 & 45 & 53.01 & 1.736 & 32 & 38.25 & 1.736 \\
\hline 172 & 46 & 53.41 & 1.757 & $33 / 34$ & 38.62 & 1.757 \\
\hline 176 & 47 & 54.57 & 1.808 & 35 & 40.05 & 1.808 \\
\hline 178 & 48 & 55.08 & 1.829 & $36 / 37$ & 0.83 & 1.829 \\
\hline 180 & 49 & 55.61 & 1.851 & 38 & 41.43 & 1.851 \\
\hline 182 & 50 & 56.07 & 1.872 & 39 & 42.12 & 1.872 \\
\hline 184 & $\mathrm{~d}$ & 56.68 & 1.900 & 40 & 43.04 & 1.900 \\
\hline 186 & 51 & 57.23 & 1.923 & 41 & 43.69 & 1.923 \\
\hline 188 & 52 & 57.78 & 1.944 & 42 & 44.32 & 1.944 \\
\hline
\end{tabular}

Notes: i-cycle codification after Lourens et al., 1996b. Ages refer to the midpoints of the sapropel (Sakamoto et al., Chap. 24, this volume) and represent 3-k.y. lagged ages of the correlative summer insolation maxima.

proposed astronomical calibration provides very accurate numerical ages not only for the sapropels (Table 2; Fig. 3B), but also for the recorded biostratigraphic datum planes (Table 1).

\section{DISCUSSION AND CONCLUSIONS}

In the Vrica section, complicating factors like the influence of obliquity, changes in sedimentation rate, and the increasing number of sapropels per large-scale cluster hinder a straightforward astro- 


\section{A Hole 969D}

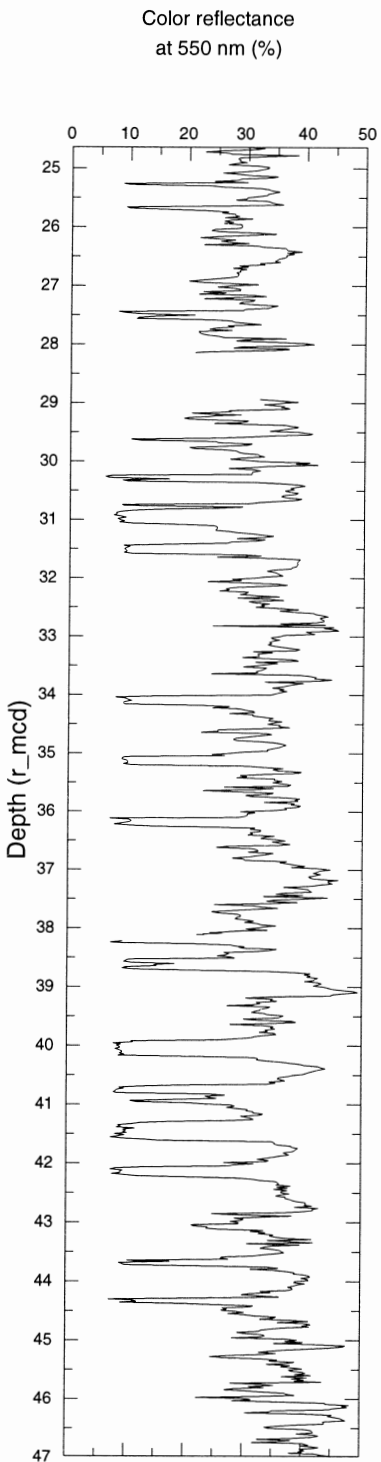

La90 $_{(1,1)}$

Summer Insolation $\left(\mathrm{W} / \mathrm{m}^{2}\right)$
Site 967

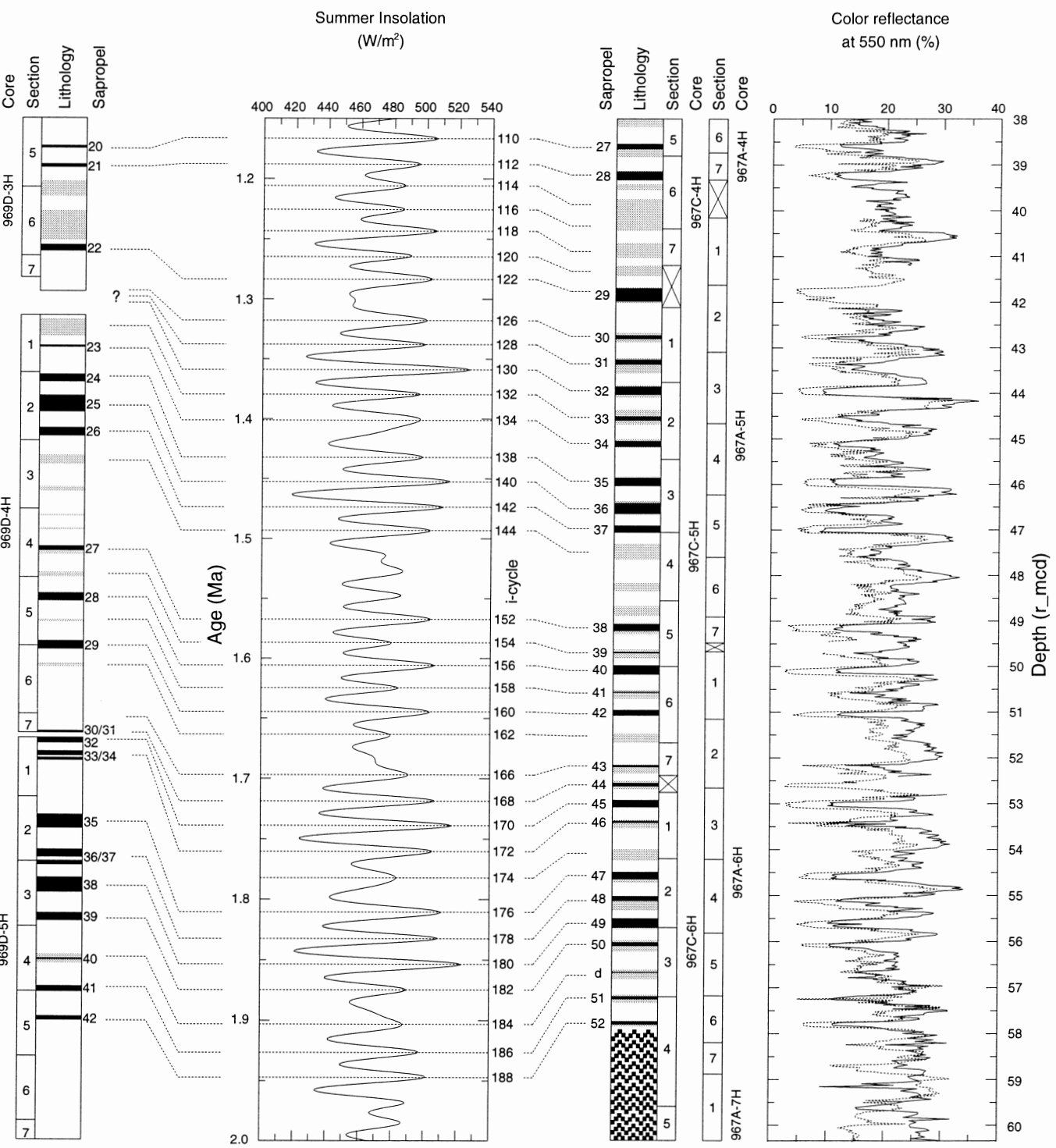

Figure 3. Calibration of early Pleistocene sapropels in Site 967 and Hole $969 \mathrm{D}$ to the La90 ${ }_{(1,1)}$ (Laskar et al., 1993) summer insolation curve at $65^{\circ} \mathrm{N}$ against (A) depth and (B) age. The color reflectance data of Hole 967A (dashed line in right column) has been shifted to the left with 10\% relative to that of Hole 967C (solid line) for clarity. All color reflectance data are obtained from Sakamoto et al. (Chap. 24, this volume). The coding (i-cycle) indicated at the right side of the insolation curve is from Lourens et al. (1996b). The jagged pattern in the lithology column of Site 967 indicates a slumped interval.

nomical calibration of the youngest $(n-v)$ sapropels (Hilgen, 1991; Lourens et al., 1996a). A key problem in establishing a sapropel chronology for this part of the Vrica section is the interpretation of the small-scale sapropel cluster n-o-p. According to the continuous age model, as referred to in the introduction, this cluster is not related to a 100-k.y. eccentricity maximum, as could be expected from late Pleistocene phase relations, but reflects an interference pattern between precession and obliquity at the time of the 400-k.y. eccentricity minimum around 1.4 Ma. Starting from this age model, all sapropel correlations between the Vrica and Singa sections and ODP Site 967 and Hole 969D are straightforward and confirmed by biostratigraphic correlations (Fig. 4). The cyclostratigraphic correlation of Sapropels $n-o-p$ with the characteristic interference pattern observed in Site 967 and Hole 969D is biostratigraphically confirmed by the position of $\mathrm{tCm}$ and blG and by influxes of G. crassaformis (Fig. 4A). The short influx above this group of sapropels is substantiated by rare $G$. cras- saformis in two successive samples above Sapropel C12 in the Singa section, but was not found in the Vrica section, possibly due to lack of sample resolution. Also, the correlation of the younger sapropels is easily accomplished. It shows that, as in the preceding interval, additional cycles are developed at the ODP sites either as grey layers or as thin indistinct sapropels. All correlations are confirmed by the position of the $\mathrm{tDb}, \mathrm{tlG}$, tHS (Fig. 4A) and by the characteristic abundance pattern of left-coiling neogloboquadrinids (Fig. 4B). Similar to the pattern observed in the Vrica section and North Atlantic Deep Sea Drilling Project (DSDP) Site 607, the peak occurrences of left-coiling neogloboquadrinids in Site 967 and Hole 969D are associated with glacial Stages 64 to 44, followed by an interval in which such (peak) occurrences are markedly absent. The next two younger peak occurrences, associated with glacial Stages 36 and 34 in the Atlantic (see Lourens et al., 1996a), are observed in the top part of the studied cores (Fig. 4B). The only remarkable difference between Vrica and 
B

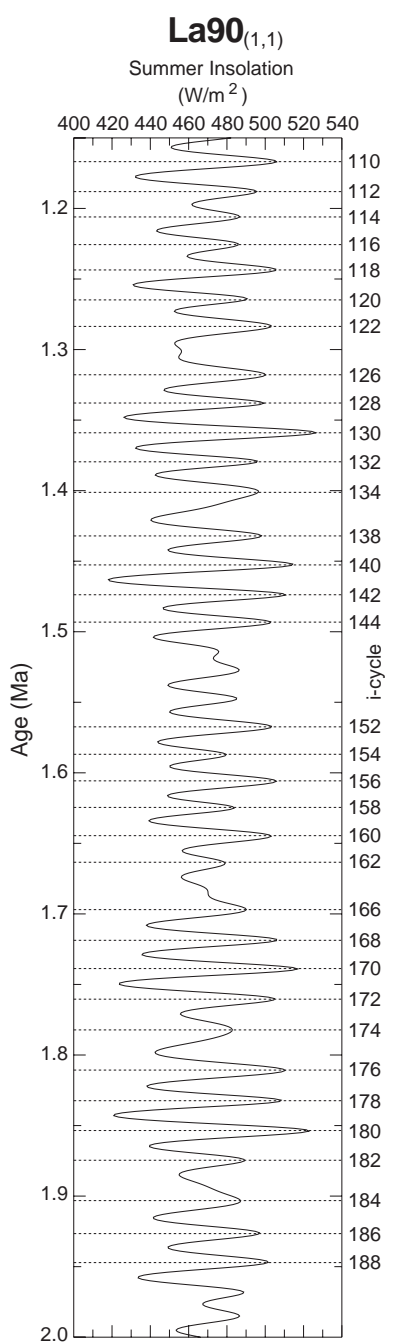

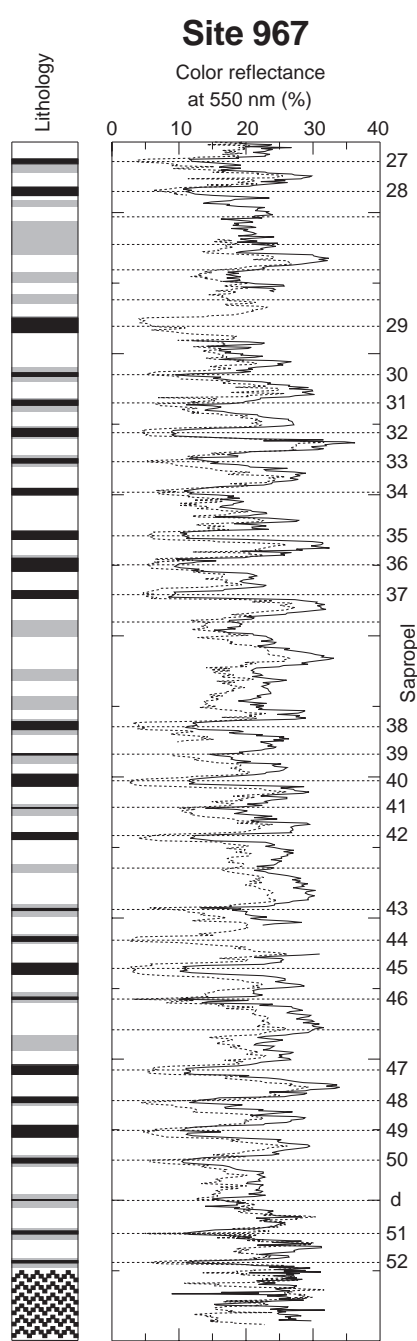

Figure 3 (continued).

the ODP sites is that the pattern of Sapropels q-r-s in the Vrica section (with $r$ being thinner and less prominent) - thought to be indicative of interference between precession and obliquity-is not confirmed at Site 967 and Hole 969D where the three correlative sapropels are equally distinct. At present, we do not have an explanation for this difference.

On the contrary, serious inconsistencies are found if we start from the alternative age model for the Vrica section. This age model, which started from the assumption that blG is globally (near-)synchronous, implied that a major hiatus is present in the interval between $\mathrm{tCm}$ and blG (Lourens et al., 1996a). A hiatus, however, is no longer tenable, because the sapropel patterns and bioevents (e.g., the first appearance of large Gephyrocapsa, the absence interval of glacial-bound influxes of left-coiling neogloboquadrinids and the $\mathrm{tlG}$ and tHS) are remarkably consistent throughout the eastern Mediterranean (Fig. 4).

To investigate the potential global diachroneity of blG, we checked the position of this event in a high-resolution sample set of ODP Site 926 (Ceara Rise, equatorial Atlantic). A comparison of our first results with the age model obtained from orbitally tuned susceptibility records (Bickert et al., 1997) reveals that the blG at this site is considerably older than the global estimate of $1.48 \mathrm{Ma}$ for this event as well (Raffi et al., 1993). The age of 1.59 Ma at Site 926 is only 30 k.y. younger than our estimate for the blG at Sites 967 and 969 in the eastern Mediterranean. In conclusion, the alternative age model for the Pleistocene Vrica section is untenable. The Vrica section contains a continuous Pleistocene succession from 1.81 (i.e., the Pliocene/ Pleistocene boundary) to $1.21 \mathrm{Ma}$.

More than $10 \mathrm{yr}$ after its formal designation as a Pliocene/Pleistocene boundary stratotype, the Vrica section can now be considered as a (land based) standard reference section for the early Pleistocene, because it is shown to contain a continuous succession. In addition, the continuity makes Vrica an appropriate section for defining the Santernian/Emilian (S/E) boundary, even though the criterion proposed by Pasini and Colalongo (1994; i.e., the FO of $H$. balthica), is less suitable because of difficulties encountered in independently confirming its position in the Vrica section (see Lourens et al., 1996a) and the diachronous nature of this event even within the Mediterranean (Fig. 4B). In contrast, the blG is (near-)synchronous in at least the eastern Mediterranean and equatorial Atlantic, and, even on a global scale, it still gives a fair approximation of the position of the S/E boundary. Nevertheless, the observed blG diachroneity of \pm 135 k.y. between the eastern Mediterranean and the North Atlantic DSDP Site 607 is almost half of the total duration (about 315 k.y.) of the Santernian as informally defined in the Vrica section. In the absence of an appropriate biostratigraphic datum plane or magnetic polarity reversal, cyclostratigraphy may guide the selection of the "golden spike" and therefore, a precession-related sapropel may represent a suitable position to define the S/E boundary. It would thereby follow the Pliocene/Pleistocene (Aguirre and Pasini, 1985), Piacenzian/Gela- 
sian (Rio et al., 1994) and Zanclean/Piacenzian (Cita et al., 1996) boundary definitions.

\section{ACKNOWLEDGMENTS}

We thank G. Ittman and G.J. Van het Veld for preparing the numerous micropaleontological samples. The review and comments of D. Castradori and K.-C. Emeis are gratefully acknowledged.

\section{REFERENCES}

Aguirre, E., and Pasini, G., 1985. The Pliocene-Pleistocene boundary. Episodes, 8:11-120.

Bickert, T., Curry, W.B., and Wefer, G., 1997. Late Pliocene to Holocene (2.6-0 Ma) western equatorial Atlantic deep-water circulation: inferences from benthic stable isotopes. Proc. ODP, Sci. Results, 154: College Station, TX (Ocean Drilling Program), 239-253.

Cita, M.B., Rio, D., Hilgen, F., Castradori, D., Lourens, L., and Vergerio, P.P., 1996. Proposal of the Global Boundary Stratotype Section and Point (GSSP) of the Piacenzian Stage (middle Pliocene). Int. Comm. on Stratigr. Subcomm. on Neogene Stratigr.

Emeis, K.-C., Robertson, A.H.F., Richter, C., et al., 1996. Proc. ODP, Init. Repts., 160: College Station, TX (Ocean Drilling Program).

Hilgen, F.J., 1991. Astronomical calibration of Gauss to Matuyama sapropels in the Mediterranean and implication for the geomagnetic polarity time scale. Earth Planet. Sci. Lett., 104:226-244.

Laskar, J., Joutel, F., and Boudin, F., 1993. Orbital, precessional, and insolation quantities for the Earth from $-20 \mathrm{Myr}$ to $+10 \mathrm{Myr}$. Astron. Astrophys., 270:522-533.
Lourens, L.J., Hilgen, F.J., Raffi, I., and Vergnaud-Grazzini, C., 1996a. Early Pleistocene chronology of the Vrica section (Calabria, Italy). Paleoceanography, 11:797-812.

Lourens, L.J., Hilgen, F.J., Zachariasse, W.J., van Hoof, A.A.M., Antonarakou, A., and Vergnaud-Grazzini, C., 1996b. Evaluation of the Plio-Pleistocene astronomical time scale. Paleoceanography, 11:391-413.

Pasini, G., and Colalongo, M.L., 1994. Proposal for the erection of the Santernian/Emilian boundary-stratotype (lower Pleistocene) and new data on the Pliocene-Pleistocene boundary-stratotype. Boll. Soc. Paleont. Ital., 33:101-120.

Raffi, I., Backman, J., Rio, D., and Shackleton, N.J., 1993. Plio-Pleistocene nannofossil biostratigraphy and calibration to oxygen isotopes stratigraphies from Deep Sea Drilling Project Site 607 and Ocean Drilling Program Site 677. Paleoceanography, 8:387-408.

Rio, D., Sprovieri, R., and Di Stefano, E., 1994. The Gelasian stage: a proposal for a new chronostratigraphic unit of the Pliocene series. Riv. Ital. Paleontol. Stratigr., 100:103-124.

Verhallen, P.J.J.M., 1991. Late Pliocene to early Pleistocene Mediterranean mud-dwelling foraminifera; influence of a changing environment on community structure and evolution. Utrecht Micropaleontol. Bull., 40:1220 .

Date of initial receipt: 6 January 1997

Date of acceptance: 7 July 1997

Ms 160SR-017

A
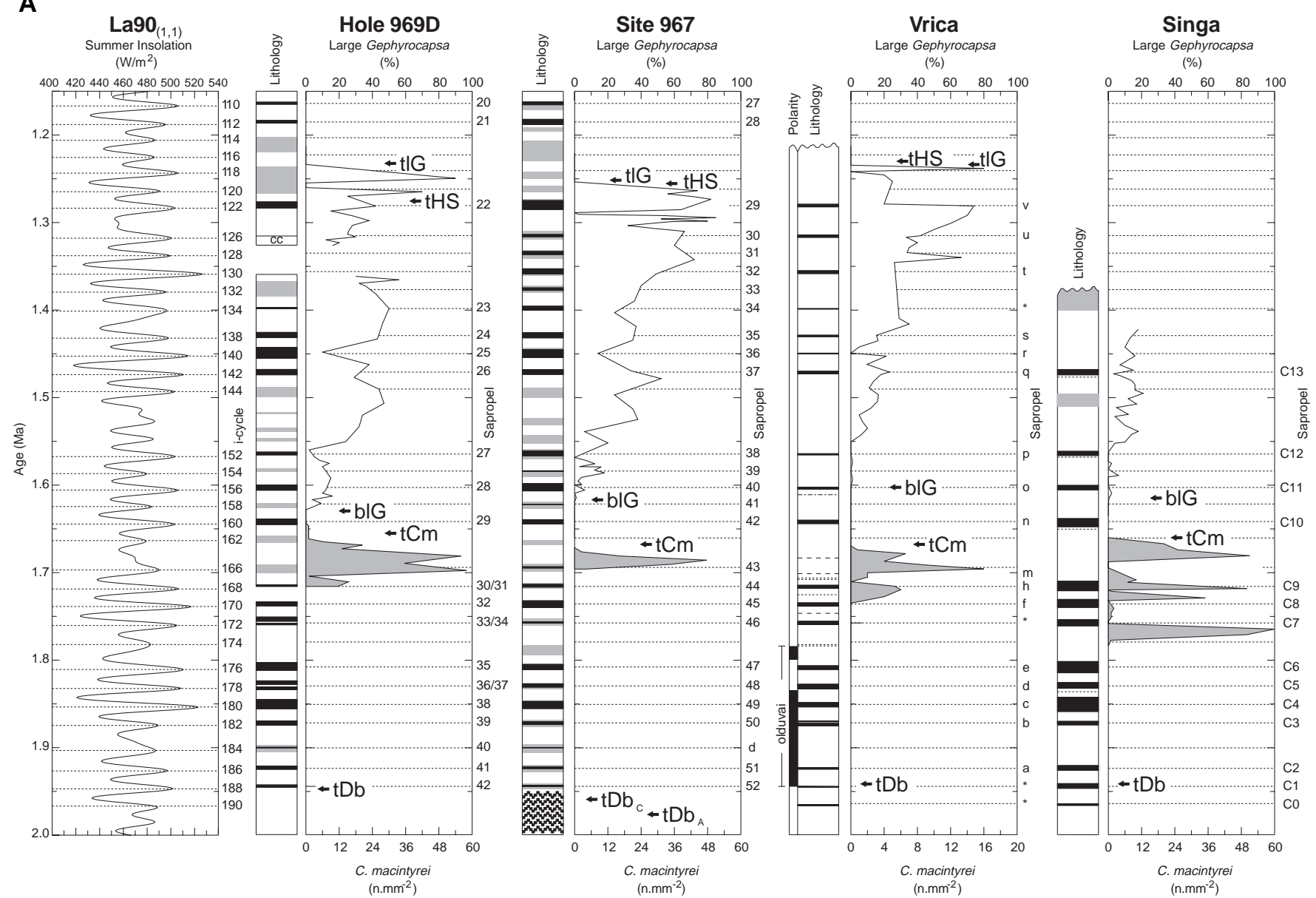

Figure 4. Comparison of the sapropel patterns and biostratigraphic datums between ODP Site 967 and Hole 969D, and the Vrica and Singa sections based on the continuous age model of Lourens et al. (1996a). See Figure 2 for definitions. A. Calcareous nannofossil events. B. Planktonic foraminifers and Hyalinea balthica. Numbers within the third column from right refer to oxygen isotopic stages. 


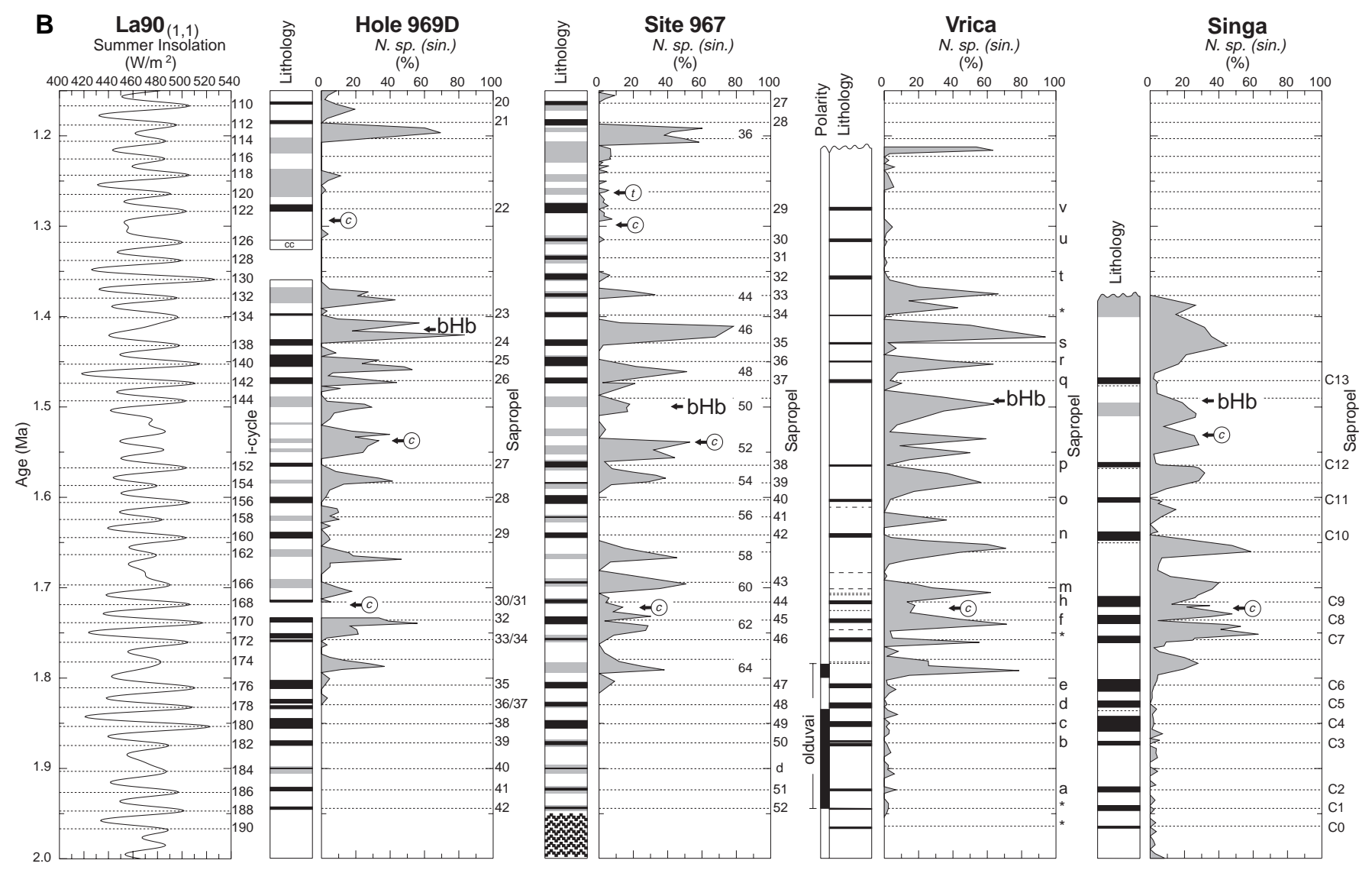

Figure 4 (continued). 